\title{
Comparison of tree volume equations for brutian pine stands in Eğirdir district
}

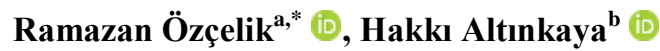

\begin{abstract}
In this study, tree volume equations have been developed for Brutian pine (Pinus brutia Ten.). The data was obtained from the natural brutian pine stands in Eğirdir region. Totally of 405 trees are sampled and randomly separated into the two groups. Since there is no real independent dataset, two-fold evaluation scheme was applied and the prediction performance of 18 models was evaluated. For this purpose, four different criteria values were used: mean error $(M D)$, mean absolute error $(M A D)$, coefficient of determination $\left(R^{2}\right)$ and root mean square error $(R M S E)$. The prediction performances of the models were evaluated on the basis of relative ranking. As a result of the evaluations, the most successful results were obtained with Model 4 , while the most unsuccessful results were obtained with model 6. The obtained results suggested that Model 4 should be used to more reliable volume predictions for natural brutian pine stands in Eğirdir Region
\end{abstract}

Keywords: Brutian pine, Volume prediction, Nonlinear models, Diameter, Relative rank

\section{Eğirdir yöresi kızılçam meşcereleri için ağaç hacim denklemlerinin karşılaştırılması}

\begin{abstract}
Özet: Bu çalışmada, Kızılçam (Pinus brutia Ten.) için ağaç hacim denklemleri geliştirilmiştir. Veriler, Eğirdir yöresi doğal kızılçam meşcerelerinden elde edilmiştir. 405 örnek ağaç ölçülmüş ve tesadüfi olarak iki gruba ayrılmıştır. Gerçek anlamda bağımsız veri setine sahip olunmadığı için çapraz geçerlilik testi uygulanarak, 18 modelin ortalama hata (MD), ortalama mutlak hata (MAD), belirtme katsayısı $\left(\mathrm{R}^{2}\right)$ ve hata kareler ortalamasının karekökü (RMSE) değerleri hesaplanmıştır. Modellerin tahmin performansları, bu dört ölçüt değeri esas alınarak hesaplanan model nisbi sıralarına göre değerlendirilmiştir. Yapılan değerlendirmeler sonucunda, en başarılı sonuçlar Model 4 ile elde edilirken, en başarısız sonuçlar model 6 ile elde edilmişsir. Elde edilen sonuçlar, Eğirdir yöresi doğal kızılçam meşcerelerinde güvenilir hacim tahminleri için Model 4'ün kullanılmasını önermektedir.
\end{abstract}

Anahtar kelimeler: Kızılçam, Hacim tahmini, Nonlinear models, Çap, Nisbi sıra

\section{Introduction}

Tree volume prediction is an key tool for estimating volume at different merchantable heights (Dieguez-Aranda et al. 2006), estimating woody biomass and assessment of carbon stocks (Zianis et al., 2005; Castedo-Dorado et al. 2012), forest management and planning (Rodríguez et al. 2014), monitoring forest health and productivity (GómezGarcía et al., 2015), and future projections of the forest products industry (de-Miguel et al. 2012). Thus, flexible and reliable volume estimation methods that also can be easily integrated to any growth and yield models are needed in order to estimate the single tree and stand volumes in Turkey (de-Miguel et al., 2012).

Tree volume equations and tree volume tables are the most popular methods for estimating the tree stem and timber volume since the past. Single, double and multi-entry tree volume models have been used to generate tree volume tables (Burkhart and Tome, 2012). It is seen that a large number of different types of models are used in the studies to develop tree volume equations (Ritchie and Hann, 1984; Hjelm and Johansson, 2012; Rachid et al., 2014). In Turkey, tree volume equations have been developed by various researchers on a regional basis (Bozkuş and Carus, 1997; Yavuz, 1999; Özkurt, 2000; Sakıc1 and Yavuz, 2003; Misır and Misır, 2004; Kahriman et al., 2017; Özçelik and Çevlik, 2017; Özçelik and Kalkanlı, 2018; Sakıcı et al. 2018).

Brutian pine is one of the most important commercial tree species in Turkey. According to the latest forest inventory data, Brutian pine covers more than 5.7 million hectares and has about 270 million $\mathrm{m}^{3}$ growing stock in our country (OGM, 2018). On the other hand, brutian pine forests play a key tool in important environmental issues such as protecting biodiversity, protection of soil and water resources, and reducing the negative impact of climate change.

Therefore, in the development of strategies for the management and planning of Brutian pine forests, wide geographic distribution, and related ecological conditions must be taken into consideration. However, in forest management plans, it is often observed that the same volume tables are used in large geographical regions without considering the differences in the growing environment. As a result of this, large and unacceptable errors can occur in volume predictions when applying a tree volume equation to trees in different areas (Brooks et al., 2008). Pillsbury et al. (1995) indicated that when volume tables or equations used by foresters without verification of their appropriateness, this practice can lead to errors in volume estimates of $40 \%$ or more. Therefore; tree volume 
tables should be generated by considering regional differences (Brooks and Wiant, 2008).

In recent years, Turkey has adopted the principles of multipurpose and ecologically-based forest management. Therefore, the General Directorate of Forestry needs to develop growth and yield prediction models for the management of forest resources. As indicated by Klos et al. (2007), one of the essential building blocks in forest growth and yield modeling are the equations for estimating individual tree volume of different tree species. However, individual tree volume equations for major tree species have not been developed in different local environmental conditions of Turkey. Since accurate volume estimations depend heavily on local environmental conditions. Therefore, successful implementation of ecosystem-based functional planning studies for brutian pine stands necessitated the development of tree volume equations for different ecological regions or local environmental conditions. On the other hand, developed individual stem volume models could help forest managers to account for regional variations in tree volume and sustainable forest management applications.

The primary objectives of this study were to develop and compare eighteen different volume equations for more accurate tree volume estimates for natural Brutian pine stands in Eğirdir Region.

\section{Material and methods}

\subsection{Material}

Data were obtained from the natural Brutian pine stands in Eğirdir Region, Isparta. Sample trees were obtained throughout the area of distribution of Britian pine in the Eğirdir Region. Total of 405 sample trees was selected for this study. The trees also were subjectively selected to ensure a representative distribution by diameter and height classes within stands. Trees possessing multiple stems, broken tops, obvious cankers or crooked boles were not included in the sample. Diameter ( $d$-diameter at breast height) of the trees were measured by the electronic caliper with the precision of $0.1 \mathrm{~cm}$ before cutting and the height (h) of the trees were measured by the tape measure with the precision of $0.05 \mathrm{~cm}$. Actual cubic volume for each tree was estimated using overlapping bolts method described by Bailey (1995).

The data were randomly divided into two groups as Group I and Group II, each containing 203 and 202 trees, respectively. Distributions of the dataset for Group I and Group II by diameter and height classes and descriptive statistics were given in Table 1, 2, and 3, respectively. Figure 1 present scatter plots of dbh versus height and dbh versus volume for Group I and Group II.

\subsection{Methods}

Based on previously published papers, in forestry studies, many tree volume equations are used in different forms in order to develop tree volume equations (Saraçoğlu, 1988; Bi and Hamilton, 1998; Yavuz, 1999; Misir and Misır, 2004; Teshome 2005; Akindele and LeMay, 2006; Perez, 2008; Alegria and Tome, 2011; Hjelm and Johansson, 2012; Stolarikova et al., 2014; Malata et al., 2017; Lee et al., 2017; Özçelik and Çevlik 2017; Kitikidou et al., 2017; Sak1c1 et al., 2018). In this study, following eighteen volume models in different forms obtained from the above-mentioned references are used.

Table 1. Distribution of sample trees by diameter and height classes for Group I

\begin{tabular}{cccccccccccccc}
\hline $\begin{array}{c}\text { Diameter } \\
(\mathrm{cm})\end{array}$ & 5 & 7 & 9 & 11 & 13 & 15 & 17 & 19 & 21 & 23 & 25 & 27 & $\Sigma$ \\
\hline 8 & 4 & 11 & 7 & & & & & & & & & & 22 \\
12 & & 3 & 20 & 11 & 4 & & & & & & & & 38 \\
16 & & & 7 & 17 & 7 & 3 & & & & & & & 34 \\
20 & & & & 5 & 3 & 4 & & 1 & & & & & 13 \\
24 & & & & & 2 & 3 & 2 & 1 & & & & & 8 \\
28 & & & & & 3 & 6 & 11 & 7 & 2 & & & & 29 \\
32 & & & & & 1 & 3 & 3 & 4 & 4 & 1 & & & 16 \\
36 & & & & & & 1 & & 3 & 4 & 1 & & 1 & 10 \\
40 & & & & & & & 1 & 2 & 5 & 3 & 1 & 1 & 13 \\
44 & & & & & & & & 2 & 3 & 1 & 2 & & 8 \\
48 & & & & & & & & 1 & 2 & 1 & 2 & 1 & 7 \\
56 & & & & & & & & & & 2 & 1 & 1 & 4 \\
60 & & & & & & & & & 1 & & & 1 \\
\hline$\Sigma$ & 4 & 14 & 34 & 33 & 20 & 20 & 17 & 21 & 20 & 10 & 6 & 4 & 203 \\
\hline
\end{tabular}

Table 2. Distribution of sample trees by diameter and height classes for Group II

\begin{tabular}{|c|c|c|c|c|c|c|c|c|c|c|c|c|c|}
\hline \multirow{2}{*}{$\begin{array}{l}\text { Diameter } \\
(\mathrm{cm})\end{array}$} & \multicolumn{12}{|c|}{ Heights (m) } & \multirow{2}{*}{$\Sigma$} \\
\hline & 5 & 7 & 9 & 11 & 13 & 15 & 17 & 19 & 21 & 23 & 25 & 27 & \\
\hline 8 & 2 & 4 & 6 & 1 & & & & & & & & & 13 \\
\hline 12 & & 7 & 19 & 11 & 2 & & & & & & & & 39 \\
\hline 16 & & 1 & 4 & 11 & 6 & 3 & & & & & & & 25 \\
\hline 20 & & & & 4 & 6 & 2 & & & & & & & 12 \\
\hline 24 & & & & & 4 & 7 & 4 & 1 & 1 & & & & 17 \\
\hline 28 & & & & & & 6 & 8 & 5 & 3 & & & & 22 \\
\hline 32 & & & & & & 5 & 2 & 9 & 5 & 1 & & & 22 \\
\hline 36 & & & & & & 2 & 3 & 5 & 6 & 2 & & & 18 \\
\hline 40 & & & & & & & 1 & 3 & & 3 & & 1 & 8 \\
\hline 44 & & & & & & & & 4 & 4 & 6 & & & 14 \\
\hline 48 & & & & & & & 1 & & & 2 & 4 & & 7 \\
\hline 56 & & & & & & & & & & 1 & 1 & & 2 \\
\hline 60 & & & & & & & & & & 2 & & & 2 \\
\hline$\Sigma$ & 2 & 12 & 29 & 27 & 18 & 25 & 19 & 27 & 19 & 17 & 5 & 2 & 202 \\
\hline
\end{tabular}

Table 3. Descriptive statistics for used trees by groups

\begin{tabular}{lcccccccc}
\hline \multirow{2}{*}{ Variables } & \multicolumn{3}{c}{ Group I $(\mathrm{n}=203)$} & \multicolumn{3}{c}{ Group II $(\mathrm{n}=202)$} \\
\cline { 2 - 9 } & Mean & Min. & Max. & S.D. & Mean & Min. & Max. & S.D. \\
\hline DBH $(\mathrm{cm})$ & 25.05 & 7.50 & 58.00 & 12.40 & 23.13 & 6.00 & 60.50 & 12.66 \\
THT $(\mathrm{m})$ & 15.12 & 5.50 & 26.50 & 5.21 & 14.48 & 4.82 & 26.50 & 5.37 \\
$\mathrm{~V}\left(\mathrm{~m}^{3}\right)$ & 0.4989 & 0.0148 & 2.6827 & 1.20 & 0.4375 & 0.0083 & 2.7128 & 0.5510 \\
\hline DBH: diameter at breast height; $T H T$ : total tree height; $V$ : tree volume.
\end{tabular}



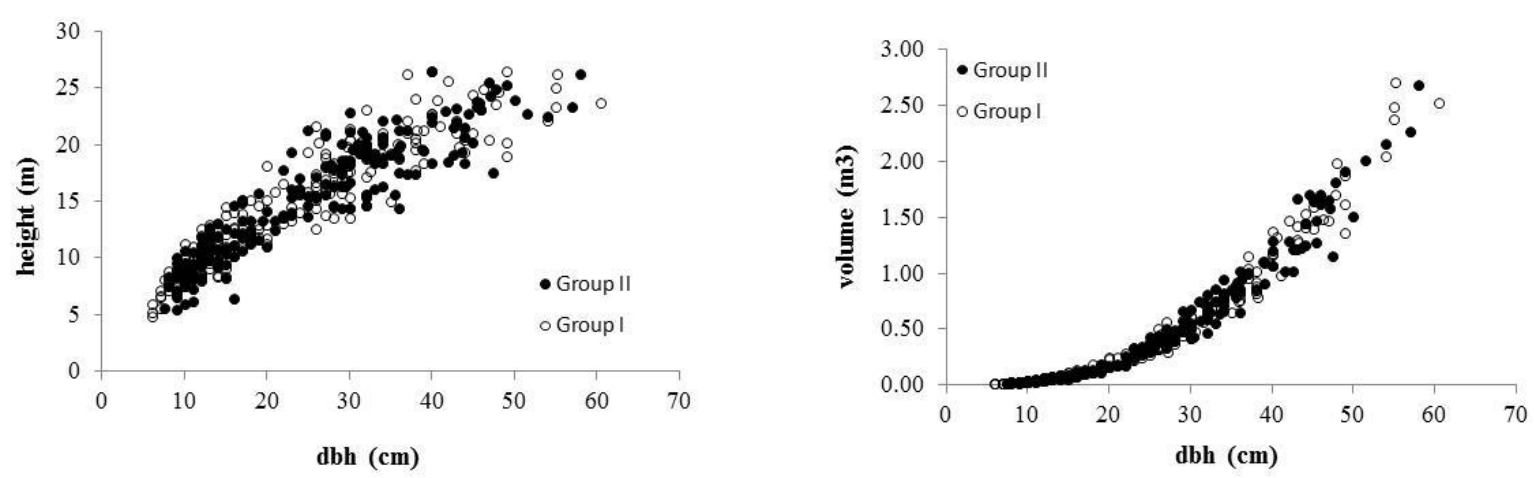

Figure 1. Scatter plots of dbh versus height and dbh versus volume for Group I and Group II

$v=\beta_{0}+\left(\beta_{1} d^{2} h\right)$

$v=\left(\beta_{0}+\beta_{1} d\right)^{2}$

$v=\beta_{0} d^{2} h$

$v=\beta_{0} d^{\beta_{1}} h^{\beta_{2}}$

$v=\frac{d^{2}}{\beta_{0}+\beta_{1} h^{-1}}$

$v=\beta_{0}+\beta_{1} d^{2} h+\beta_{2} h$

$v=\frac{d^{2} h}{\beta_{0}+\beta_{1} d}$

$v=\beta_{0}\left(2+\frac{d}{h}\right)+\beta_{1} h^{2}+\beta_{2} d h^{2}$

$v=\beta_{0}+\beta_{1}(h / d)^{\beta_{2}} d^{2} h$

$v=d^{2}\left(\beta_{0}+\beta_{1} h\right)$

$v=\beta_{0} d^{2}+\beta_{1} d^{2} h-\beta_{2} d^{2} h^{2}-\beta_{3} d h+\beta_{4} d h^{2}$

$v=\beta_{0}+\beta_{1} d^{2} h+\beta_{2} d^{3} h+\beta_{3} d^{2} h^{2}+\beta_{4} h$

$v=\beta_{0}\left(d^{2} h\right)^{\beta_{1}}$

$v=\beta_{0}\left(d^{2}\right)^{\beta_{1}} h^{\beta_{2}}$

$v=\beta_{0}+\beta_{1} d^{2}+\beta_{2} d^{2} h^{2}$

$v=\beta_{0}+\beta_{1} d+\beta_{2} d^{2}+\beta_{3} d^{2} h^{2}$

$v=\beta_{0}+\beta_{1} d h+\beta_{2} d h^{2}+\beta_{3} d^{2} h^{2}$

$v=\beta_{0}+\beta_{1} d+\beta_{2} d h^{2}+\beta_{3} d^{2} h^{2}$

The models were fitted Marquardt method using PROC NLIN procedure in SAS 9.4 software (SAS Institute Inc. 2010).

\subsubsection{Model evaluation}

The accuracy of stem volume predictions for each model was judged by numerical and graphical assessment of the residuals. As suggested by Kozak and Kozak (2003), validation of the models must be tested using an independent data set. In the absence of independent data, different methods are suggested. Therefore, we used the
(Borset, 1954)

Perez and Kanninen (2003)

(Spurr, 1952)

(Schumacher-Hall, 1973)

(Honer, 1967)

(Rachid-Casnati et al., 2014)

(Takata, 1958)

(Hjelm and Johansson, 2012)

(Teshome, 2005)

(Ogaya, 1968)

(Eriksson, 1973)

(Bi and Hamilton, 1998)

(Malata et al., 2017)

(Malata et al., 2017)

(Alegria and Tome, 2011)

(Alegria and Tome, 2011)

(Alegria and Tome, 2011)

(Alegria and Tome, 2011)

two-fold evaluation scheme to evaluate the performance of models (Bohora and Cao, 2014; Özçelik et al., 2018) in which parameters of volume equations fitted to one group was applied to predict for the other group. The predictions from both groups were then used to calculate evaluation statistics for different volume equations..

The eighteen tree volume equations were evaluated using the following error statistics:

Mean Difference $(M D)=\frac{\sum_{i=1}^{i=n}\left(y_{i}-\hat{y}_{i}\right)}{n}$

Mean absolute difference $(M A D)=\frac{\sum_{i=1}^{i=n}\left|y_{i}-\hat{y}_{i}\right|}{n}$ 
$R^{2}=1-\left[\frac{\sum_{i=1}^{i=n}\left(y_{i}-\hat{y}_{i}\right)^{2}}{\sum_{i=1}^{i=n}\left(y_{i}-\bar{y}\right)^{2}}\right]$

Root Mean Square Error $(R M S E)=\sqrt{\frac{\sum_{i=1}^{i=n}\left(y_{i}-\hat{y}_{i}\right)^{2}}{n-p}}$

where, $y_{i}, \hat{y}_{i}$, and $\bar{y}$ are the observed, predicted, and average values of the dependent variable, respectively; $n$ is the observation numbers, and $p$ is the number of model parameters.

As indicated by Poudel and Cao (2013), the traditional standard or ordinal ranks show the order of the methods but fail to exhibit the exact positions of the methods compared with another one. Therefore, the relative rank, introduced by Poudel and Cao (2013), used in this study to show the relative position of the different models. The relative rank of model $i$ is defined as:

$R_{i}=1+\frac{(m-1)\left(S_{i}-S_{\min }\right)}{S_{\max }-S_{\min }}$

where $R_{i}$ is the relative rank of model $i(i=1,2, \ldots, m), m$ is the number of methods evaluated, $S_{i}$ is the error statistics produced by model $i, S_{\min }$ is the minimum value of $S_{i}$, and $S_{\max }$ is the maximum value of $S_{i}$.

In the rank system, the best and the worst models have relative ranks of 1 and $m$, respectively. Ranks of the remaining models are expressed as real numbers between 1 and $m$. Because the magnitude, and not only the order of the $S_{i}$ 's are taken into consideration, this ranking system should provide more information than the traditional ordinal ranks. After a relative rank was computed separately for each error statistics (MD, MAD, $\mathrm{R}^{2}$, and RMSE) of each method, a final rank was calculated based on the sum of all ranks for each method.

\section{Results and discussion}

In this study, stem volume prediction models were developed for natural brutian pine trees in Eğirdir Region using eighteen nonlinear models. Parameters for each model estimated from the entire dataset are presented in Table 4. All $t$-statistics for parameters of the eighteen models were significant at $\alpha=0.0001$ except for some models.

Four error statistics computed to compare and evaluate of stem volume estimation models using two-fold evaluation schemes (Table 5). The results showed that, except for model (6), more than $97 \%$ of the variation in volume predictions was explained by all models. The mean difference ranged from -0.002 to 0.0095 , MAD values ranged from 0.0410 to 0.0749 , and RMSE values ranged from 0.0744 to 0.1190 for tested models.

The relative ranks were obtained from the means of the error statistics for the eighteen methods are shown in Table 6. Model 4 produced fitting statistics that were better than those from the rest of the models. As a result, the Model 4 took part as the most successful model among all 18 models analyzed in this study, whereas Model 6 was the poorest performer. The results also indicated that model 1, 5, 3, 14, and 17 performed quite well for brutian pine trees.
Table 4. Parameter estimates of eighteen volume equations for all dataset

\begin{tabular}{|c|c|c|c|c|c|c|}
\hline \multirow{2}{*}{$\begin{array}{c}\text { Model } \\
\text { no }\end{array}$} & \multicolumn{6}{|c|}{ Parameters } \\
\hline & $\beta_{0}$ & $\beta_{1}$ & $\beta_{2}$ & $\beta_{3}$ & $\beta_{4}$ & $\beta_{5}$ \\
\hline 1 & $\begin{array}{c}0.016037 \\
* * * *\end{array}$ & $\begin{array}{c}0.000034 \\
* * * *\end{array}$ & & & & \\
\hline 2 & $\begin{array}{c}-0.17497 \\
* * * *\end{array}$ & $\begin{array}{c}0.030688 \\
* * * *\end{array}$ & & & & \\
\hline 3 & $\begin{array}{c}0.000032 \\
\text { **** }\end{array}$ & & & & & \\
\hline 4 & $\begin{array}{c}0.000076 \\
\text { **** }\end{array}$ & $\begin{array}{c}2.039836 \\
* * * *\end{array}$ & $\begin{array}{c}0.67574 \\
* * * *\end{array}$ & & & \\
\hline 5 & $\begin{array}{c}421.3998 \\
\text { **** }\end{array}$ & $\begin{array}{c}21550,34 \\
* * * *\end{array}$ & & & & \\
\hline 6 & $\begin{array}{c}-0.00092 \\
\text { NS }\end{array}$ & $\begin{array}{c}0.000032 \\
* * *\end{array}$ & $\begin{array}{c}0.001542 \\
\text { NS }\end{array}$ & & & \\
\hline 7 & $\begin{array}{c}26836.09 \\
* * * *\end{array}$ & $\begin{array}{c}90.71855 \\
* * * *\end{array}$ & & & & \\
\hline 8 & $\begin{array}{c}0.504665 \\
\text { **** }\end{array}$ & $\begin{array}{c}-0.00158 \\
* * * *\end{array}$ & $\begin{array}{c}0.000097 \\
* * * *\end{array}$ & & & \\
\hline 9 & $\begin{array}{c}0.019895 \\
\text { *** }\end{array}$ & $\begin{array}{c}0.00003 \\
* * * *\end{array}$ & $\begin{array}{c}-0.0648 \\
*\end{array}$ & & & \\
\hline 10 & $\begin{array}{c}0.000179 \\
\text { **** }\end{array}$ & $\begin{array}{c}0.000024 \\
* * * *\end{array}$ & & & & \\
\hline 11 & $\begin{array}{c}0.000376 \\
*\end{array}$ & $\begin{array}{c}0.000021 \\
*\end{array}$ & $\underset{\mathrm{NS}}{2.49 \times 10^{-7}}$ & $\begin{array}{c}0.00053 \\
* *\end{array}$ & $\begin{array}{c}0.000023 \\
* *\end{array}$ & \\
\hline 12 & $\begin{array}{c}-0.0348 \\
*\end{array}$ & $\begin{array}{c}0.000289 \\
* * * *\end{array}$ & $\begin{array}{c}2.243049 \\
* * * *\end{array}$ & $\begin{array}{c}0.001482 \\
* * * *\end{array}$ & $\begin{array}{c}-135.017 \\
* * * *\end{array}$ & $\begin{array}{c}-19.3492 \\
* * * * *\end{array}$ \\
\hline 13 & $\begin{array}{c}0.000058 \\
* * * *\end{array}$ & $\begin{array}{c}0.945777 \\
* * * *\end{array}$ & & & & \\
\hline 14 & $\begin{array}{c}0.000076 \\
\text { **** }\end{array}$ & $\begin{array}{c}1.019908 \\
* * * *\end{array}$ & $\begin{array}{c}0.675667 \\
* * * *\end{array}$ & & & \\
\hline 15 & $\begin{array}{c}-0.003088 \\
\text { **** }\end{array}$ & $\begin{array}{c}0.000483 \\
* * *\end{array}$ & $\begin{array}{l}4.99 \times 10^{-7} \\
* * * *\end{array}$ & & & \\
\hline 16 & $\begin{array}{c}-0.02213 \\
\text { NS }\end{array}$ & $\begin{array}{c}-0.0009 \\
\text { NS }\end{array}$ & $\begin{array}{c}0.000506 \\
* * * *\end{array}$ & $\begin{array}{c}4.87 \times 10^{-7} \\
* * * *\end{array}$ & & \\
\hline 17 & $\begin{array}{c}-0.10603 \\
\text { **** }\end{array}$ & $\begin{array}{c}0.001867 \\
* * * *\end{array}$ & $\begin{array}{c}-0.00008 \\
\quad * * * *\end{array}$ & $\begin{array}{c}1.35 \times 10^{-6} \\
* * * *\end{array}$ & & \\
\hline 18 & $\begin{array}{c}-0.19175 \\
* * * *\end{array}$ & $\begin{array}{c}0.020497 \\
* * * *\end{array}$ & $\begin{array}{c}-0.00002 \\
* * * *\end{array}$ & $\begin{array}{c}1.18 \times 10^{-6} \\
* * * * *\end{array}$ & & \\
\hline
\end{tabular}

Table 5. The two-fold evaluation for tested models

\begin{tabular}{ccccc}
\hline Model no & MD & MAD & $\mathrm{R}^{2}$ & RMSE \\
\hline 1 & 0.0018 & 0.0412 & 0.9808 & 0.0753 \\
2 & 0.0002 & 0.0464 & 0.9799 & 0.0773 \\
3 & $\underline{0.0001}$ & 0.0457 & 0.9797 & 0.0775 \\
4 & 0.0022 & $\underline{0.0410}$ & $\underline{0.9813}$ & $\underline{0.0744}$ \\
5 & 0.0018 & 0.0421 & 0.9811 & 0.0749 \\
6 & 0.0079 & 0.0749 & 0.9522 & 0.1190 \\
7 & 0.0029 & 0.0431 & 0.9812 & 0.0746 \\
8 & 0.0022 & 0.0447 & 0.9802 & 0.0766 \\
9 & 0.0023 & 0.0516 & 0.9752 & 0.0857 \\
10 & 0.0048 & 0.0447 & 0.9812 & 0.0746 \\
11 & 0.0022 & 0.0516 & 0.9752 & 0.0857 \\
12 & 0.0095 & 0.0428 & 0.9796 & 0.0777 \\
13 & 0.0008 & 0.0439 & 0.9798 & 0.0773 \\
14 & 0.0002 & 0.0469 & 0.9800 & 0.0770 \\
15 & 0.0017 & 0.0445 & 0.9812 & 0.0745 \\
16 & 0.0017 & 0.0441 & 0.9812 & 0.0745 \\
17 & 0.0022 & 0.0529 & 0.9784 & 0.0800 \\
18 & 0.0024 & 0.0557 & 0.9774 & 0.0819 \\
\hline
\end{tabular}


Table 6. Relative ranks for eighteen methods

\begin{tabular}{|c|c|c|c|c|c|c|}
\hline \multirow{2}{*}{ Model no } & \multicolumn{4}{|c|}{ Relative rank } & \multirow{2}{*}{ Sum of Ranks } & \multirow{2}{*}{ Overall Rank } \\
\hline & MD & MAD & $\mathrm{R}^{2}$ & RMSE & & \\
\hline 1 & 4.07447 & 1.10029 & 1.29210 & 1.34305 & 7.80991 & 1.00334 \\
\hline 2 & 1.18085 & 3.70796 & 1.81787 & 2.10538 & 8.81207 & 1.28122 \\
\hline 3 & $\underline{1.00000}$ & 3.35693 & 1.93471 & 2.18161 & 8.47325 & 1.18727 \\
\hline$\underline{4}$ & $\overline{4.79787}$ & $\underline{1.00000}$ & $\underline{1.00000}$ & $\underline{1.00000}$ & 7.79787 & $\underline{1.00000}$ \\
\hline 5 & 4.07447 & 1.55162 & $\overline{1.11684}$ & $\overline{1.19058}$ & 7.93351 & $\overline{1.03761}$ \\
\hline 6 & 15.10638 & 18.00000 & 18.00000 & 18.00000 & 69.10638 & 18.00000 \\
\hline 7 & 6.06383 & 2.05310 & $\overline{1.05842}$ & 1.07623 & 10.25158 & 1.68038 \\
\hline 8 & 4.79787 & 2.85546 & 1.64261 & 1.83857 & 11.13451 & 1.92520 \\
\hline 9 & 4.79787 & 6.31563 & 4.56357 & 5.30717 & 20.98426 & 4.65640 \\
\hline 10 & 9.50000 & 2.85546 & 1.05842 & 1.07623 & 14.49011 & 2.85566 \\
\hline 11 & 4.79787 & 6.31563 & 4.56357 & 5.30717 & 20.98426 & 4.65640 \\
\hline 12 & 18.00000 & 1.90265 & 1.99313 & 2.25785 & 24.15363 & 5.53522 \\
\hline 13 & 2.26596 & 2.45428 & 1.87629 & 2.10538 & 8.70190 & 1.25068 \\
\hline 14 & 1.18085 & 3.95870 & 1.75945 & 1.99103 & 8.89003 & 1.30284 \\
\hline 15 & 3.89362 & 2.75516 & 1.05842 & 1.03812 & 8.74532 & 1.26271 \\
\hline 16 & 3.89362 & 2.55457 & 1.05842 & 1.03812 & 8.54473 & 1.20709 \\
\hline 17 & 4.79787 & 6.96755 & 2.69416 & 3.13453 & 17.59411 & 3.71636 \\
\hline 18 & 5.15957 & 8.37168 & 3.27835 & 3.85874 & 20.66835 & 4.56881 \\
\hline
\end{tabular}

Relative rankings of the 18 models are presented as a radar graph in Figure 2. Each method is represented by a quadrilateral, whose area is smallest for the best method and largest for the worst method. The largest area in Figure 2 belongs to model 6 which ranked last in all four evaluation statistics. The radar chart shows that the eighteen models can be grouped into three general groups. The successful methods include models $4,1,5,3,14,16,2,13,14,7$, and 8 . The areas of these models are almost indistinguishable from one another. The intermediate groups consist of models 12, 17, and 18, 11, 9 and 12. The last group, which produced higher values for error statistics, consisted of model 6 with model 6 being ranked last in three statistics and next to last in another. These visual results are consistent with the overall rankings presented in Table 6 .

Figure 3 shows residual plots for the estimated volume values for the three most successful and poorest models in terms of their relative ranking values. Considering the Loess regression line, the residual plots for successful models are obtained relatively more accurately, but for unsuccessful models are relatively inaccurate. It is seen that the Loess regression line of Model 6 and Model 12, which are the most unsuccessful models in particular, is quite distinct from the zero line. On the other hand, the Loess regression line of the most successful model, Model 4 and Model 1, seems to be close to the zero line.

Figure 4 shows the distribution of the measured volume values for the best (models 4, 1, and 5) and the worst (models 6, 13 and 9) versus to the estimated volume values. As indicated by Huang et al. (2000), observedVol= $a+b *$ PredictedVol, was fitted on the data in Figure 4 using a simple linear model. If significant estimation errors are present, the model intercept will not equal zero $(a \neq 0)$ and slope will not equal one $(b \neq 1)$. Estimated values were regressed against observed values to look for possible prediction error in the model. Confidence intervals were obtained for the model intercept and slope. The best models (Model 4, Model 1 and Model 5) not showed a biased estimation for diameters. For example; using the Model 4, confidence interval ranged from -0.01568 to 0.0036 and from 0.99359 to 1.02073 for the model intercept and slope, respectively. These results exhibited that the intercept was not significantly different from zero and the slope was not significantly different form one. Similar results were obtained for Model 1 and 5. The worst models (Model 6, Model 9 and Model 12) showed a biased estimation for diameters. For example; using the Model 12, confidence interval ranged from 0.00627 to 0.002585 and ranged from 0.97198 to 0.99943 for the model intercept and slope, respectively. The results exhibited that the intercept and the slope were significantly different from zero and form one, respectively. Similar results were found for the other models. In general, for all models, separation from the 1:1 line is relatively higher for large volumes.

To evaluate the models' performance for different tree sizes, models further evaluated by dbh and height classes. Figures 5 show the error distribution of some models by diameter and height classes. Successful models tend to produce negative residuals in the thin and middle diameter classes, whereas unsuccessful models produce a positive residual. However, error variance of all models is increased for thick diameter classes. A similar situation can be seen in Figure 5 in the distribution of errors for height classes. The error variance increases as the tree height increases.
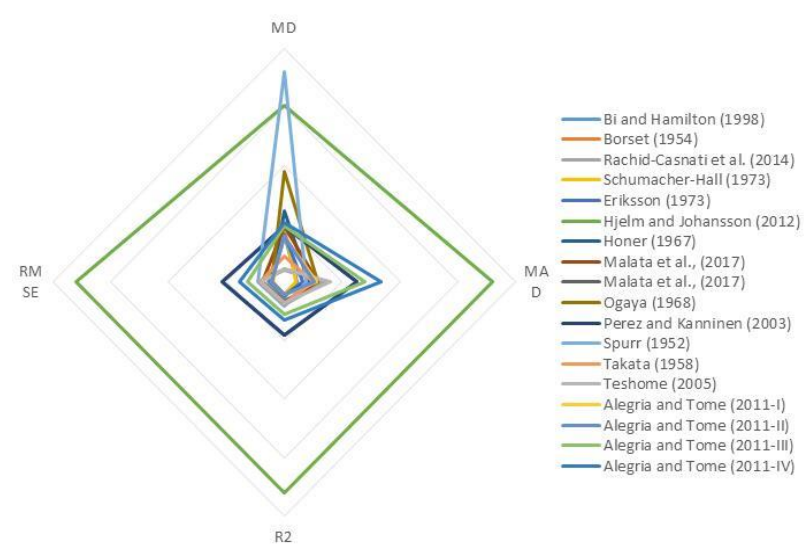

Figure 2. Relative ranks for eighteen volume equations. Method resulting in the smallest area inside the box represents the best method 


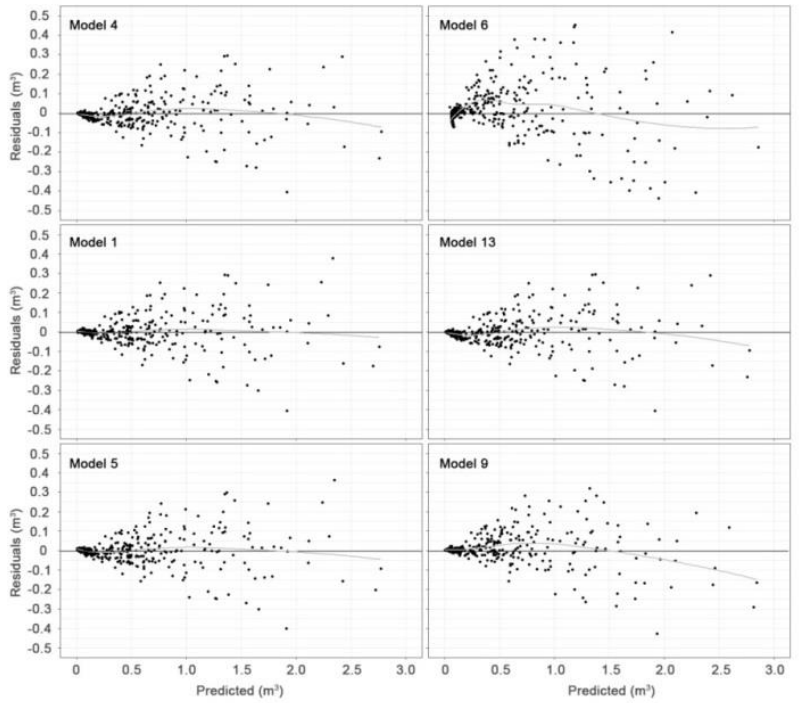

Figure 3. Residual plots of developed volume models (the best models in the left column and the worst models in the right column). Blackline is loess line for natural brutian pine trees

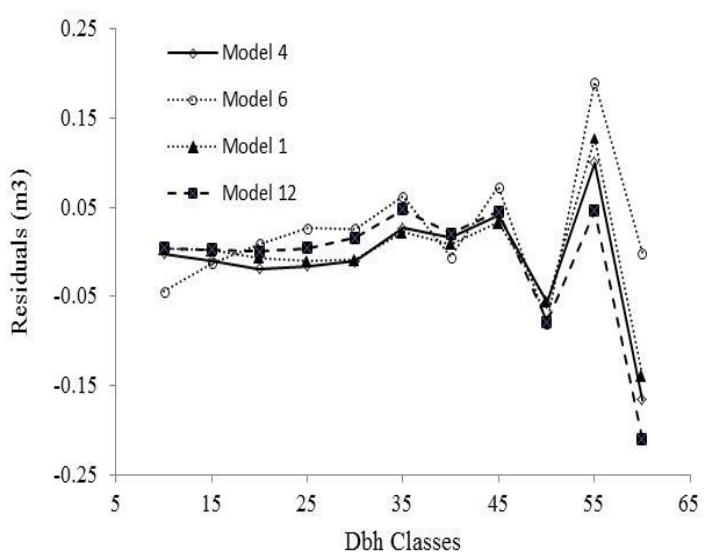

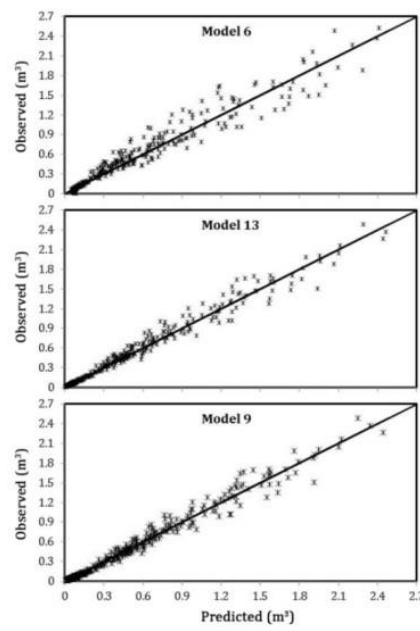

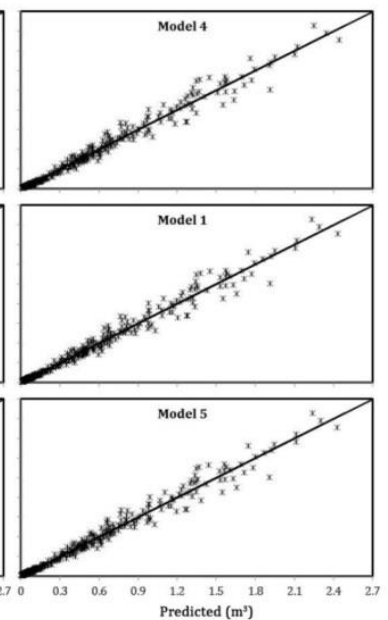

Figure 4. The $45^{\circ}$ line plots for the best models (right column) and the worst models (left column)

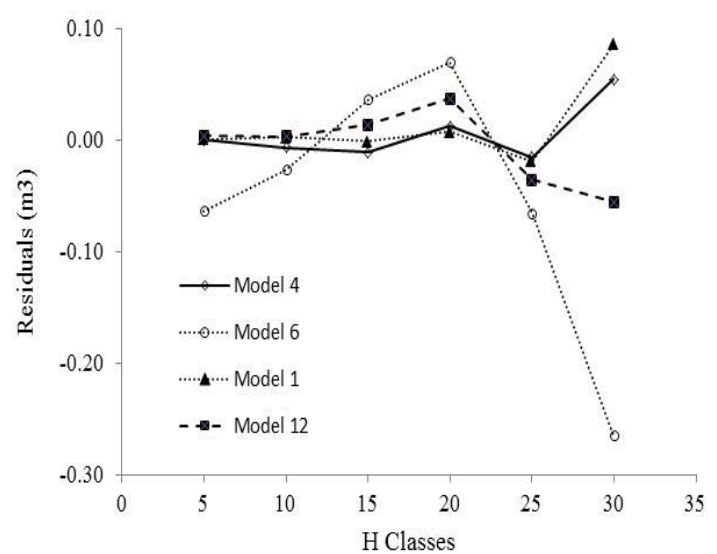

Figure 5. Residuals by dbh and height classes of some developed volume models

According to the results of this study, Model 4, which is proposed as the most successful model are compared with the other researchers' equations (Alemdağ, 1962; Çatal 2009; Kahriman et al., 2017) in terms of the volume estimation success. The results of these comparisons are shown in Table 7. It is seen that Model 4 is more successful than other models in this comparison of mean error and RMSE values. This clearly reveals the importance of localization in tree volume estimations. Because models proposed by Çatal (2009), Kahriman et al. (2017) and Alemdağ (1962) were developed with the data collected from Western Mediterranean Region, Antalya, and Mersin Regional and wide entire distribution range of Brutian pine respectively, it is quite normal for these models to produce higher errors. Local ecological conditions have a significant effect on the tree stem form and accordingly the diameter and height growth of the trees. Tree volume equations developed for larger geographic regions are not sufficient to explain the variation in tree form, unlike the regional tree volume equations.
Table 7. Comparison of results obtained from different volume equations

\begin{tabular}{lcc}
\hline Volume equation & $\mathrm{MD}\left(\mathrm{m}^{3}\right)$ & $\mathrm{RMSE}\left(\mathrm{m}^{3}\right)$ \\
\hline Model 4 & -0.0047 & 0.0721 \\
Alemdağ (1962) & 0.0046 & 0.0748 \\
Çatal (2009) & 0.0455 & 0.0976 \\
Kahriman et. al., (2017) & -0.0159 & 0.0764 \\
\hline
\end{tabular}

As a result; since the model 4 is a widely used model for tree volume estimations in forestry studies and contains fewer parameters compared to many other model forms, this model can be suggested for estimating single tree and stand volumes in natural brutian pine stands for Eğirdir Region. On the other hand, the results of paired $t$-test concluded that the Model 4 (Schumacher-Hall, 1973) could be used safely in regional aspect at the significance level $\mathrm{p}>0.05$ 


\section{Conclusions}

In this study, stem volume equations are developed and compared for natural brutian pine stands in Eğirdir region. For this purpose, 18 different tree volume equations are tested using relative ranks of models, based on 4 different performance criteria. Total of 405 trees are sampled and randomly separated into the two groups and these groups are used to parameter estimations and calculate to error statistics. Based on statistical evaluations and graphical examination, Model 4 is the best model to predict tree volume for brutian pine in Eğirdir Region. Considering the relative ranking of the models, there are no significant differences between the Model 4, 1, 3, 5, 7, 14 and 17. However, Model 4 is a well-known and widely used model and it is preferred to other models because it allows comparison with other studies.

Measuring the tree height and breast height diameter will be sufficient to estimate tree volume with the equation developed in the relevant area. Tree volume can be estimated $\mathrm{as}^{3}$ by replacing these values in the related tree volume equation.

In this study, Model 4, the suggested equation for the Brutian pine volume estimation, is compared with the volume estimations obtained from the two-entry volume tables that are developed by Alemdağ (1962), Çatal (2009) ve Kahriman et al.. (2017). The results showed that these models gave a higher residual in volume estimation. This situation suggests that the regional conditions should be taken into consideration while developing the tree volume equations.

As a result, tree volumes can be estimated for natural brutian pine stands using model 4 (Schumacher-Hill, 1973). However, as a rule, as long as the possibilities can be given and a sufficient amount of sample trees can be measured, the development of separate volume equations for each region and tree species will be more useful to explain the variability in tree form and to make more accurate the volume estimates.

\section{Acknowledgments}

This study was supported by Scientific Research Projects Coordination Unit of Süleyman Demirel University, Project no: BAP-5053-YL1-17.

\section{References}

Akindele, S.O., LeMay, V.M., 2006. Development of tree volume equations for common timber species in tropical rain forest area of Nigeria. Forest Ecology and Management, 226: 41-48.

Alegria, C., Tome, M., 2011. A set of models of individual tree merchantable volume prediction for Pinus pinaster Aiton in central inland of Portugal. European Journal of Forest Research, 130:871879.

Alemdağ, Ş., 1962. Development, yield and management rules of Red pine (Pinus brutia Ten.) forests in Turkey. Technical Bulletin of Forestry research Institute No:11, 160s., Ankara.

Bailey, R.L., 1995. Upper stem volumes from stem analysis data: an overlapping bolts method. Can J. For. Res., 26(1): 170-173

Bi H., Hamilton, F., 1998. Stem volume equations for native tree species in southern New South Wales and Victoria. Australian Forestry 61(4): 275-286.

Børset, O., 1954. Volume computation of standing aspen. Commun Norweigan For Assoc, 43:397-447.
Bohora, S.B., Cao, Q.V., 2014. Prediction of tree diamater growth using quantile regression and mixed-effects models. Forest Ecology and Management, 319:62-66.

Bozkuş,H.F. ve Carus,S., 1997. Toros Göknarı (Abies cilicica Carr.) ve Sedir (Cedrus libani Link.) in Çift Girişli Gövde Hacim Tabloları ve Mevcut Tablolarla Karşılaştırılması, İstanbul Üniversitesi Orman Fakültesi Dergisi, Seri A, Cilt 47, Sayı 1, 51-70.

Brooks, J.R., Jiang, L., Özçelik, R., 2008. Compatible stem volume and taper equations for Brutian Pine, Cedar of Lebanon, and Cilicica Fir in Turkey. Forest Ecology and Management, 256:147-151.

Brooks, J.R., Wiant, H.V., 2008. Ecoregion Based Local Volume Equations for Appalachian Hardwoods. Northern Journal of Applied Forestry, 25(2): 87-92.

Burkhart, H.E., Tome, M., 2012. Modeling Forest Trees and Stands. Springer, Dordrecht.

Castedo-Dorado, F., Gómez-García, E., Diéguez-Aranda, U., BarrioAnta, M., Crecente-Campo, F., 2012. Aboveground stand-level biomass estimation: a comparison of two methods for major forest species in northwest Spain. Annals of Forest Science, 69: 735-746.

Clutter, J.L., Fortson, J.C., Pienaar, L.V., Bailey, R.L., 1983. Timber Management: A Quantitative Approach. Krieger Publishing Company, Malabar, Florida.

Çatal, Y., 2009. Batı Akdeniz Bölgesi Kızılçam (Pinus brutia Ten.) Meşcerelerinde Artım ve Büyüme. Doktora Tezi, Süleyman Demirel Üniversitesi Fen bilimleri Enstitüsü, Isparta.

de-Miguel, S., Mehtätalo, L., Shater, Z., Kraid, B., Pukkala, T., 2012. Evaluating marginal and conditional predictions of taper models in the absence of calibration data. Can. J. For. Res., 42: 1383-1394.

Diéguez-Aranda, U., Castedo-Dorado, F., Alvarez-Gonzalez, J.G., Rojo, A., 2006. Compatible taper function for scots pine plantations in Nortwestern Spain. Canadian Journal of Forest, 36(5): 1190-1205.

Eriksson, H., 1973. Volymfunktioner för stående träd av ask, asp, klibbal och contorta-tall. [Tree volume functions for ash, aspen, alder and lodgepole pine in Sweden. (Fraxinus excelsior L., Populus tremula L., Alnus glutinosa (L.) Gartn., Pinus contorta Dougl. var. latifolia Engelm.).] Skogshögskolan, Institutionen för skogsproduktion, Stockholm. Rapporter og Uppsatser nr. 26-1973. $26 \mathrm{p}$.

Gómez-García, E., Crecente-Campo, F., Barrio-Anta, M., DiéguezAranda, U., 2015. A disaggregated dynamic model for predicting volume, biomass and carbon stocks in even-aged pedunculate oak stands in Galicia (NW Spain). European Journal of Forest research, 134: 569-583.

Hjelm, B., Johansson, T., 2012. Volume equations for poplars growing on farmland in Sweden. Scandinavian Journal of Forest Research, 27:561-566.

Honer, T., 1967. Standard volume tables and merchantable conversion factors for the commercial tree species of central and eastern Canada. For Manage Res and Serv Inst, Inf Rep FMR-X-5, Ottawa.

Kahriman, A., Sönmez, T., Şahin, A., 2017. Antalya ve Mersin yöresi kızılçam meşcereleri için ağaç hacim tabloları. Kastamonu Üniversitesi Orman Fakültesi Dergisi, 17(1): 9-22.

Kelly, T.F., Beltz, R.C., 1987. A Comparison of Tree Volume Estimation Models for Forest Inventory, USDA Forest Service, Southern Forest Experiment Station, Research Paper SO-233.

Kitikidou, K., Milios, E., Radoglou, K., 2017. Single-entry volume table for Pius brutia in panted peri-urban forest. Annals of Silvicultural Research, 41(2): 74-79.

Klos, R.J., Wang, G.G., Dang, Q.L., East. E.W., 2007. Taper equations for five major commercial tree species in Manitoba, Canada. West. J. Appl. For., 22: 163-170.

Kozak, A., Kozak, R.A., 2003. Does cross validation provide additional information in the evaluation of regression models? Canadian Journal of Forest Research, 33, 976-987.

Lee, D., Seo, Y., Choi, J., 2017. Estimation and validation of stem volume equations for Pinus densiflora, Pinus koraiensis, and Larix kaempferi in South Korea. Forest Science and Technology, 13:7782.

Misır, N., Misır, M., 2004. Developing double-entry tree volume table for Ash in Turkey. Kafkas University, Artvin Faculty of Forestry 3(4):135-144.

Ogaya, N., 1968. Kubierungsformeln und Bestandesmassenformeln. Inaugural. Doctoral dissertation, Dissertation-. Univ., Nat.-Math. Fak, Freiburg. 
OGM, 2018. Ormancilı İstatistikleri, Orman Genel Müdürlüğü,Ankara.

Özçelik, R., Çevlik, M., 2017. Batı Akdeniz Yöresi doğal sedir meşcereleri için hacim denklemleri. Turkish Journal of Forestry, 18:68-86.

Özçelik, R., Kalkanlı, Ş., 2018. Kaş Yöresi doğal kızılçam (Pinus brutia Ten.) meşcereleri için ağaç hacim denklemlerinin geliştirlmesi. Turkish Journal of Forestry, 19 (1): 9-19.

Özçelik, R., Cao, Q.V., Trincado, G., Göçer, N., 2018. Predicting tree height from diamater and dominant height using mixed-effects and quantile regression models for two species in Turkey. Forest Ecology and Management, 419-420:240-248.

Özkurt, A., 2000. Volume table for Eucalyptus grandis W. Hill ex. Maiden. Journal of Eastern Mediterranean Forestry Reseach Institute 6: 87-105.

Perez, D., 2008. Growth and volume equations developed from stem analysis for Tectora grandis in Costa Rica. Journal of Tropical Forest Science, 20: 66-75.

Pillsbury, N.H., McDonald, P.M., Simon, V., 1995. Reliability of Tanoak volume equations when applied to different areas. Western Journal of Applied Forestry, 10(2): 72-78.

Poudel, K.P., Cao, Q.V., 2013. Evaluation of methods to predict Weibull parameters for characterizing diameter distributions. For. Sci., 59(2): 243-252.

Rachid Casnati, C., Mason, E.G., Woollons, R., Resquin, F., 2014. Volume and taper equations for P. teada (L.) and E. grandis (Hill ex. Maiden). Agrociencia Uruguay, 18(2): 47-60.

Ritchie, M.W., Hann, D.W., 1984. Nonlinear equations for predicting diameter and squared diamter inside bark at breast height for Douglas-fir. Oregon State University, Forest Research Lab., Research Paper 47, 17p.
Rodríguez, F., Lizarralde, I., Fernandez-Landa, A., Condes, S., 2014. Non-destructive measurement techniques for taper equation development: a study case in the Spanish Northern Iberian Range. European Journal of Forest Research, 133: 213-223.

Sakıcı, O.E., Yavuz, H., 2003. Volume equations for Bormullerian Fir stands in Ilgaz Mountain. Gazi University Faculty of Forestry Journal, 3(2): 155-168.

Sakıcı, O.E., Sağlam, F., Seki, M., 2018. Single-and Double-entry volume equations for Crimean pine stands in Kastamonu Regional Directorate of Forestry. Turkish Jounral of Forestry, 19(19): 20-29.

Saraçoğlu, N., 1988. Stem volume table for Alder (Alnus glutinosa Gaertn subsp. Barbata (C.A. Mey.) Yalt.). Tr. J. Of Agriculture and Forestry, 22:215-225.

Schumacher, F.X., Hall, F.D.S., 1933. Logarithmic expression of timber-tree volume. J. Agric. Res., 47: 719-734.

Spurr, S.H., 1952. Forest Inventory. Ronald Press, New York.

Stolarikova, R., Salek, L., Zeahradnik, D., Dragoun, L., Jerabkova, L., Marusak, R., Merganic, J., 2014. Comparison of tree volume equations for small-leaved lime (Tilia cordota Mill.) in the Czech Republic. Scandinavian Journal of Forest Research, 29:757-763.

Takata, K., 1958. Construction of universal diameter-height-curves. Journal of Japanese Forest Society, 40:1.

Teshome, T., 2005. Analysis of individual tree volume equations for Cupressus Lusitanica in Munessa Forest, Ethiopia. Southern African Forestry Journal, 203: 27-32.

Yavuz, H., 1999. Volume equations and volume tables for Black pine in Taşköprü. Turkish Journal of Agriculture and Forestry, 23: 1181-1188.

Zianis, D., Muukkonen, P., Menuccini, M., 2005. Biomass and stem volume equations for tree species in Europe. Silva Fenn. Monogr., $4: 63$. 